\title{
Nexus Between Corporate Governance and Firm Performance in Malaysia: Supervised Machine Learning Approach
}

http://doi.org/10.21272/fmir.3(1).115-130.2019

\section{Md. Nur-Al-Ahad}

Master Student, Graduate School of Engineering, Toyohashi University of Technology, Japan

\section{Syeda Nusrat}

Lecturer, Faculty of Business Administration, University of Science and Technology, Chittagong, Bangladesh

\section{Vagavi Prakash}

Lecturer, Gedu College of Business Studies, Royal University of Bhutan, Bhutan

\begin{abstract}
In the wake of the Asian Financial Crisis in 1997 which had significantly affected Malaysia' economy, there has been a renewed emphasis on corporate governance in order to make companies more effective and to further mitigate risks. However, despite the importance of the emerging technology companies in Malaysia in consideration of the modern internet age, there has not been many studies conducted on the Malaysian technology sector in respect of corporate governance. This study aims to partially bridge the research gap by investigating the relationship between selected corporate governance attributes and financial performance of Malaysian technology companies. This study involves 27 Malaysian technology companies listed on Bursa Malaysia, using annual data from the year 2010 to 2014. A multiple regression analysis was iii employed to examine the relationship between selected corporate governance attributes of the companies and their financial performance, relying on the financial ratios, namely Return on Assets and Return on Equity. Measures of corporate governance attributes employed are independent directors on the board, board gender diversity and independent audit committee. The results showed that board gender diversity had a positive impact on the financial performance of Malaysian technology companies, while the effects of independent directors and independent audit committee are not established.
\end{abstract}

Keywords: Corporate Governance, Technology Firms, Financial Performance, Machine Learning.

JEL Classification: G3, G38.

Cite as: Nur-Al-Ahad Md., Syeda N., Vagavi P. (2019). Nexus Between Corporate Governance and Firm Performance in Malaysia: Supervised Machine Learning Approach. Financial Markets, Institutions and Risks, 3(1), 115-131. http://doi.org/10.21272/fmir.3(1).115-130.2019.

(C) The Authors, 2019. This article is published with open access at Sumy State University.

\section{Introduction}

Concerns on corporate governance had come to the forefront of the world after the Enron Corporation (Enron) scandal which started to unfold in October 2001. The scandal eventually led to the bankruptcy of the Enron Corporation, an American energy company based in Houston, Texas, in December 2001 and the dissolution of Arthur Andersen, which was one of the five largest audit and accountancy partnerships in the world. In the short span of three months, Enron had fallen from being 'Fortune's most innovative' company for seven consecutive years to a company which is most remembered for its corporate governance failures (Abid \& Ahmed, 2014). Since then, a series of corporate scandals and fraud led to the destruction of shareholders' wealth, loss of employees' wellbeing, increased in white-collar crimes and record-breaking bankruptcy filings (Solomon, 2010). In the face of such scandals and fraud, there has been a renewed emphasis on corporate governance.

In the Asian context, the lack of corporate governance mechanisms and practices had been perceived to be one of the major causes of the 1997 Asian Financial Crisis. This evidence is especially affirmed as most Asian countries have pursued to strengthen the corporate governance, transparency and disclosure levels since the said crisis (Ho \& Wong, 2001).

In Malaysia, the Asian Financial Crisis in 1997 not only introduced the term of corporate governance but also drew the attention of the public about the weaknesses of Malaysian corporate governance practices (Abidin 
Financial Markets, Institutions and Risks, Volume 3, Issue 1, 2019

ISSN (online) - 2521-1242 ISSN (print) - 2521-1250

\& Ahmad, 2007). The financial crisis by Malaysia generated a substantial amount of analysis and debate largely focussed on macro-economic issues, systemic stability as well as issues pertaining to the regulation of international investors, the role and function of regulators and the need to improve disclosure and the governance system as expounded by High Level Finance Committee on Corporate Governance of Malaysia (1999) in its Report on Corporate Governance February 1999.

After 1998, the Malaysian government made a decision to adopt corporate reforms that could enhance the quality of good corporate management practice. In recognising the importance of raising the standards of corporate governance, the Malaysian Code on Corporate Governance (MCCG) (2012) was first introduced by the High-Level Finance Committee on Corporate Governance in 2000 to set out principles and best practices on structures and processes that companies may use in their operations towards achieving the optimal governance framework. This was later revised in 2007, 2011 and the latest, 2012.

Studies have shown that good governance may and most likely help to generate investor goodwill and confidence. According to Gompers et al. (2003), good corporate governance improves valuations and enhances financial performance. Consequently, greater transparency of the business operations and financial situation of a company may determine the degree of investor's confidence.

Good governance practices would possibly have a significant impact on company performance with strategic decisions and effective monitoring conducted by the board of directors. In short, corporate governance may directly impact a firm's financial performance. Various researches have been previously conducted on corporate governance and financial performance amongst Malaysian listed companies. However, there have not been many which analyze specific sectors as most are performed on the generally large facet of corporate governance. Despite the importance of the emerging technology companies in Malaysia in consideration of the modern IT age, there has been a little emphasis on studies done in relation to the Malaysian technology sector. Hence, this study has been geared towards finding the nexus between corporate governance and firm performance in the Malaysian context with a particular emphasis on technology firms in Malaysia.

\section{Theoretical Framework}

\section{Corporate Governance}

In Malaysia, corporate governance is defined by the High-Level Finance Committee on Corporate Governance of Malaysia (1999) as "the process and structure used to direct and manage the business affairs of the company towards enhancing business prosperity and corporate accountability with the ultimate objective of realizing long-term shareholder value whilst taking into account the interest of other stakeholders".

Besides the generally accepted definition above, numerous definitions of corporate governance is adopted by Malaysian researchers. Noordin (1999) stated that corporate governance relates to transparency and accountability of how the company presents itself to various parties that have legitimate interests in its affairs, such as shareholders, creditors, and investors. Corporate governance can be described as "the proper procedure on how the "government" of a company (the managers and board of directors), should be responsible to their "voters" (the shareholders, creditors, and investors)" (Abidin \& Ahmad, 2007). Khas (2002) had narrowly defined corporate governance as "a system that governs and controls an organization which comprises internal and external processes, management accountability and transparency through effective internal control system".

\section{Corporate Governance in the Technology Sector}

As previously stated, literature or empirical studies relevant to corporate governance issues in Malaysian technology companies are surprisingly thin. The same goes for technology firms in other countries. In Australia, a study was conducted by Imam, Ahmed and Tickle (2012) on a sample of 55 Australian public listed information technology companies to find the relationship between corporate governance characteristics with company performance. In contrast with many studies which found that independent directors have a positive effect on the company performance, the study showed that the performance of information technology companies was worse when there was a higher degree of board independence. For Malaysia, Haron, Ibrahim, and Muhamad (2008) investigated the linkage between the attributes of the board and corporate performance in the construction and technology sectors between the financial year 2000 and 2001. The study found that there are certain aspects of board attributes and control functions that differ between the two sectors, and these significantly influence firm performance. This finding thus confirms the differences in business nature and environment between the two sectors. 


\section{Corporate Governance and Financial Performance in Malaysia}

In Malaysia, according to Sulaiman et al. (2012), the model of the board seems to perform well with a sound corporate governance system built by High-Level Finance Committee of Corporate Governance. Similarly, Klapper et al. (2004) on the study between 14 emerging economies found that, in terms of corporate governance, firm level in Malaysia performed well in comparison to other developed countries.

Literature has revealed contradictory results on the positive contribution of corporate governance towards companies' financial performance. For instance, Ponnu (2008) conducted a study to examine the effects of corporate governance on the financial performance of Malaysian public listed companies using data for the years of 1999 and 2005 and it was found that there was no significant relationship between corporate governance structure and financial performance.

Mokhtar et al (2009) further examined the relationship between good corporate governance practices and financial performance by clustering good corporate governance practices and weak corporate governance practices. Contrary to expectations, the results revealed no difference in terms of performance for both clusters. According to Haniffa and Hudaib (2006), the result may be due to the Malaysian business environment which is characterized by high level of ownership concentration where the scenario portrays only a few people holding ownership in most companies in Malaysia.

\section{Independent Directors and Financial Performance}

According to Abdullah (2004), the board of directors is observed as a group of people responsible for the strategic direction of a company. The board of directors holds fiduciary responsibilities to lead and direct a company and ensure the correctness of management's approach in transforming the corporate goals. Thus, it is critical for the company to ensure that the board composition is independent of management. This is due to the fact that the board composition possibly could reduce the principal-agent problem, as the involvement of independent directors improves the company's ability to remain competitive.

The significance of independent directors as a corporate governance attribute was evidence with the revision of MCCG in 2012. It emphasizes the role of independent directors in bringing an independent and objective judgment to the board which helps to mitigate risks arising from the conflict of interest or undue influence from interested parties (MCCG, 2012).

Kamardin and Haron (2011) found that independent director is significantly related to the performance of a company. This is also confirmed by Saat et al (2011) where a study was conducted using 221 samples of Malaysian public listed companies to investigate the influence of a high number of independent directors on firm value. The results showed that firm performance is enhanced when the board composition is solely consisting of independent non-executive directors.

Research by Khan and Awan (2012) also supported the above implication in which they concluded that amongst 91 sample companies listed on the Karachi Stock Exchange, the companies with their boards heavily occupied by independent directors showed greater company performance in the forms of return on assets, return on equity and Tobin's Q. In another study which focuses on non-financial companies listed on the Shanghai and Shenzhen stock exchanges in 2003 and 2004, Ma and Tian (2009) found that company performance is positively and significantly related to the number of independent directors and also the proportion of independent directors on the board.

However, in contrast, a study by Annuar and Shamser (1994) provided evidence using share market movement during board changes, that there was no significant effect of board composition on the wealth of the companies. This argument is also supported by Ponnu (2010) where the study found that the number of outsiders appointed as directors did not bring any improvement towards the company's performance.

A study of a sample consisting of thirty-eight number of companies in Nigeria during the 2009 financial year by Paul et al. (2011) also concluded that there is no significant relationship between the percentage of the board member constituted of the independent directors and corporate performance and an organization cannot improve its economic performance by raising the independent directors on its board. Sakawa, Watanabel, and Ben-Zion (2009) also found no significant relationship between the independent directors' ratio and company performance using a sample comprising data of 522 manufacturing companies listed in the Tokyo Stock Exchange during 1991-1995.

Even though the findings varied, the evidence supports the contribution of independent directors on financial performance. This is due to the fact that these directors are anticipated to be independent. Therefore, it is 
Financial Markets, Institutions and Risks, Volume 3, Issue 1, 2019 ISSN (online) - 2521-1242 ISSN (print) - 2521-1250

assumed that a higher number of independent directors in board composition reveals that the company is being scrutinized effectively and consequently, the company will be more financially performing.

\section{Board Gender Diversity and Financial Performance}

Research on the relationship between board gender diversity and firm performance has produced mixed results. Some studies in developed countries have found positive results from having women represented on boards. For example, Lukerath-Rovers (2011) found that firms in the Netherlands with women directors perform better in terms of ROE than firms without women on their boards. This may be because board gender diversity allows a greater range of perspectives to be considered, so boards reach better decisions. Similarly, Campbell and Vera (2009) found positive short-term (stock market) impacts and positive long-term impacts (firm value) for Spanish firms whose boards included one or more women.

Several other researchers have also come to the same conclusion that board gender diversity has a positive effect on firm performance. Carter et al. (2003) explain the relationship between board gender diversity and firm performance based on the agency theory and they posit that board gender diversity enhances the board's ability to monitor top management. In addition to this, they argue that increasing the number of female directors may increase the board's independence since women tend to ask questions that male directors may not ask. Minguez-Vera and Campbell (2008) for instance, found this to be the case in Spain. Even though firm performance was measured by Tobin's Q, the results were similar to those of accounting measures like return on assets and return on investment. This study, however, did not consider all firms in Spain in that financial sector firms were eliminated from the sample. This study also focused on only companies listed on the continuous market of Madrid.

In as much different studies from different countries have established the positive impact of board gender diversity on firm performance, others still established a negative impact. This shows how inconclusive the concept of gender diversity is. For instance, Bøhren and Strøm (2007) established a negative relationship between board gender diversity and firm performance for Norwegian firms. Meanwhile, in the USA, Adams, and Ferreira (2009) found a negative average effect of gender diversity on firm performance.

Other the other hand, there have been studies which showed that board gender diversity has no effect on firm performance. Haslam et al. (2010) found no relationship between the presence of women on the boards of UK firms with the firms' accounting performance measured as ROA and ROE. A study in Pakistan (Yasser, 2012) found no significant relationship between board gender diversity and firm performance measured as economic value added. Other studies that found no relationship between gender diversity and firm performance include Kochan et al. (2003) while studying the US firms.

In Malaysia, Abdullah et al. (2013) found a positive and significant relationship between the presence of women directors and Malaysian firms' accounting performance as measured by ROA. They attributed this to women's distinctive managerial style. However, other studies in Malaysia have found otherwise (e.g., Shukeri et al. (2012); Marimuthu \& Kolandaisamy (2009).

\section{Independent Audit Committee and Financial Performance}

The audit committee is seen as an effective subcommittee of a board of directors, which is important in good corporate governance (Abbott, Park \& Parker, 2000; Jensen \& Meckling, 1976). Garcia-Meca and SanchezBallesta (2009) argue that an independent audit committee could enhance the quality and credibility of financial reporting. Cohen and Hanno (2000) emphasize the significance of audit committee independence to appraise management actions regarding risk assessment.

An audit committee is an important corporate governance mechanism in firms to protect the interests of shareholders and oversee financial reporting (Mallin, 2007). Chan and Li (2008) find a significant positive relationship between Tobin's Q and audit committee independence. Hamdan, Sarea, and Reyad (2013) examine the relationship between audit committee independence and firm performance of 106 financial firms listed on the Amman Stock Exchange Market from 2008 to 2009, finding that audit committee independence has a significant influence on firm performance.

Triki and Bouaziz (2012) investigate the effect of the audit committee's characteristics on financial performance, measured by ROA and ROE, of a sample of 26 Tunisian firms listed on the Tunis Stock Exchange from 2007 to 2010 . The results show the essential role of the audit committee in protecting the interests of shareholders, as well as the effect of the audit committee's characteristics on the financial performance of Tunisian companies. Similarly, Tornyeva and Wereko (2012) investigate the relationship 
between corporate governance and the financial performance of insurance companies from 2005 to 2009 in Ghana. The findings show that audit committee independence is positively associated with the financial performance of insurance companies in Ghana.

Nevertheless, Al-Matari et al. (2012) argue that although a positive relationship between audit committee independence and firm performance is expected, and that an independent audit committee can reduce agency problems, there is no relationship between audit committee independence and marketing performance. Using a sample of 20 non-financial listed companies in Nigeria, Kajola (2008) does not find a significant association between audit committee composition and firm performance. The author also finds that having a majority of independent non-executive directors in the audit committee does not have a significant influence on firm performance.

Ghabayen (2012) investigates the relationship between audit committee composition and firm performance using the annual reports of 102 listed non-financial firms in the Saudi market in 2011. The results reveal that the audit committee composition has no effect on firm performance in the selected sample. This result is supported by Klein (1998), whose research fails to find any significant relationship between the proportion of independent directors on the audit committee and firm performance.

Even though there is empirical evidence that may underscore the view of the contribution of an independent audit committee towards financial performance, nevertheless, literature reviews discussed mostly yielded positive association between the independence of audit committee and firm's financial performance. Therefore, it is anticipated that an independent audit committee will yield a more effective board, thus contributing positively to the firm's financial performance.

\section{Research Methodology}

The study is quantitative in nature. The study is based on secondary data. Data pertaining to this study have been collected from secondary resources mainly from the annual reports of the chosen companies. Assuming that it would have the convenience and accurate representation of the technology sector in Malaysia, the sampling frame in this study consists of all public listed technology companies in Malaysia. The sample identified in this study was selected based on the listed companies which have been categorized under the technology sector by Bursa Malaysia. The sample consisted of 27 listed technology companies on Bursa Malaysia from 2010 to 2014, resulting in total observations of 135 annual reports for the four years. Four companies have been excluded from the sample size due to their change of financial year which resulted in certain data not being represented for this study. The sample size of 27 companies represents about 2.98 percent of 906 companies listed on Bursa Malaysia as at 31 December 2014, extracted from Bursa Malaysia Berhad 2014 Annual Report. The research examines the relationship between corporate governance attributes on financial performance. Hence, corporate governance is the independent variable here and firm performance is the dependent variable here. Several proxy variables have been chosen for these two variables. Following is a figure showing the representative proxy variables for this study.

Table 1. Variables

\begin{tabular}{|l|c|c|}
\hline Variables & Proxies & Codes \\
\hline Independent Variables & Independent Directors & INDDIR \\
\hline & Board Gender Diversity & IAC \\
\hline & Independent Audit Committee & ROA \\
\hline Dependent Variable & Return on Asset & ROE \\
\hline
\end{tabular}

Source: by authors through secondary data analysis.

The dependent variable of the financial performance of the companies is influenced by three independent variables i.e. independent directors, board gender diversity and independent audit committee. Fama and Jensen (1983) found the presence of independent directors' lead to better monitoring of the board and reduce managerial opportunism. There are suggestions that deviation from male-dominated boards brings about informational and social diversity that improves performance (Dezsö \& Ross, 2012). Anderson, Mansi, and Reeb (2004) found that full independent audit committees bring about lower debt financing costs which indicate that all the members must be independent before there could be any significant impact.

This study employs Return on Asset (ROA) and Return on Equity (ROE) as a financial measurement for the financial performance of the companies. Haat, Rahman, and Mahenthiran (2008) provide empirical evidence for the effect of corporate governance practices on firm performance by using ROA and ROE as proxies of performance among a sample of 50 non-finance firms listed on stock exchanges in Pakistan from 2003 to 
Financial Markets, Institutions and Risks, Volume 3, Issue 1, 2019 ISSN (online) - 2521-1242 ISSN (print) - 2521-1250

2005. Heenetigala and Armstrong (2011) investigate the effect of corporate governance practices on firm performance and utilize ROA, ROE and Tobin's Q to measure performance using data from the annual reports of a sample of 37 companies in Sri Lanka in 2003 and 2007. As Lamport, Seetanah, and Sannassee (2011) state, 'there is no agreed consensus on which proxy is the best'. Consequently, the conceptual framework utilizes comprehensive measures based on accounting formulas (ROA and ROE) for financial performance. These are commonly used measures to assess firm performance and have also been used in previous research on corporate governance and firm performance (Sengur, 2011).

From the chosen variables, two models have been formulated for this study. The models are -

$$
\begin{aligned}
& \mathrm{ROA}=\lambda 0+\lambda 1 \mathrm{INDDIR}+\lambda 2 \mathrm{BGD}+\lambda 3 \mathrm{I} \\
& \mathrm{ROE}=\lambda 0+\lambda 1 \mathrm{INDDIR}+\lambda 2 \mathrm{BGD}+\lambda 3 \mathrm{IAC}
\end{aligned}
$$

After the selection of the model, the collected data have been analyzed using machine learning approach. Machine learning is one of the highly used topics these days. Machine learning is a field that focuses on drawing conclusions from large amounts of data. This is done by letting a model find structures and relationships in the data. By presenting a machine learning model with samples from a data set the model learns to represent hidden relationships and patterns in the data. The field of machine learning combines computation and statistics (Bishop, 2006). There are different types of machine learning approaches mainly supervised learning, unsupervised learning and reinforcement learning. In this study, supervised machine learning approach has been utilized.

\section{Analysis and Discussion}

Descriptive Statistics. Table 1 presents descriptive statistics for all variables of interest for the average of five years from the year 2010 to 2014. Based on the table, there are a total of 135 observations which comprised of 27 technology companies that adequately formed relevant data for the five-year period.

\begin{tabular}{|c|c|c|c|c|c|c|c|c|c|c|}
\hline & $\mathrm{N}$ & Min. & Max. & Mean & Std. Deviation & Variance & \multicolumn{2}{|c|}{ Skewness } & \multicolumn{2}{|c|}{ Kurtosis } \\
\hline & Statistic & Statistic & Statistic & Statistic & Statistic & Statistic & Statistic & Std. Error & Statistic & Std. Error \\
\hline $\begin{array}{l}\text { ID (Independent } \\
\text { Directors) }\end{array}$ & 135 & .2500 & .8330 & .4677 & .1166 & .014 & .609 & .209 & .022 & .414 \\
\hline $\begin{array}{l}\text { BGD (Board Gender } \\
\text { Diversity) }\end{array}$ & 135 & 0 & 1 & .56 & .499 & .249 & -.226 & .209 & -1.978 & .414 \\
\hline $\begin{array}{l}\text { IAC (Independent } \\
\text { Audit Committee) }\end{array}$ & 135 & 0 & 1 & .54 & .500 & .250 & -.165 & .209 & -2.003 & .414 \\
\hline Valid N (listwise) & 135 & & & & & & & & & \\
\hline
\end{tabular}

Table 2. Descriptive Statistics for Independent Variables

Source: by authors through secondary data analysis.

The mean score of independent directors is $47 \%$, indicating that almost half of the directors are independent. The mean score for board gender diversity is 0.56 , reflecting more than half of the boards have women directors. The mean presence of independent audit committee is 0.54 , indicating that more than half of the sample companies have implemented such committee, which in turn highlights the emphasis placed by the listed companies on corporate governance. This mean reveals the relatively average degree of independence among audit committee members.

In addition, the maximum average of independent directors on the board is 0.83 , while the minimum average board composition is 0.25 , indicating limited variation in the composition of board practices among the companies. The statistics reveals that the minimum value for independent directors was 0.2500 , whilst the same for the other two independent variables, board gender diversity and independent audit committee, were both 0 . For maximum value, the figure for independent directors was 0.8330 . Board gender diversity and independent audit committee had the same maximum value which in this analysis is 1 .

Table 2. Descriptive Statistics for Dependent Variables

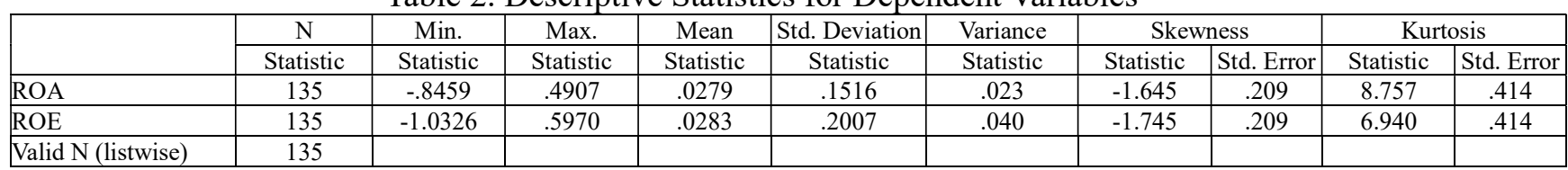

Source: by authors through secondary data analysis.

Table 2 shows the descriptive statistics of the two financial performance measures i.e. ROA and ROE. The mean value for ROA is $0.03 \%$, with a minimum of $-0.85 \%$ and a maximum of $0.49 \%$. The ROE averages around $0.03 \%$, with a minimum value of $-1.03 \%$ and a maximum value of $0.60 \%$. There is an indication of the slowdown of the economy as suggested by the negative minimum value of both ROA and ROE figures. 
Following are some figures showing distribution curves for the variables-
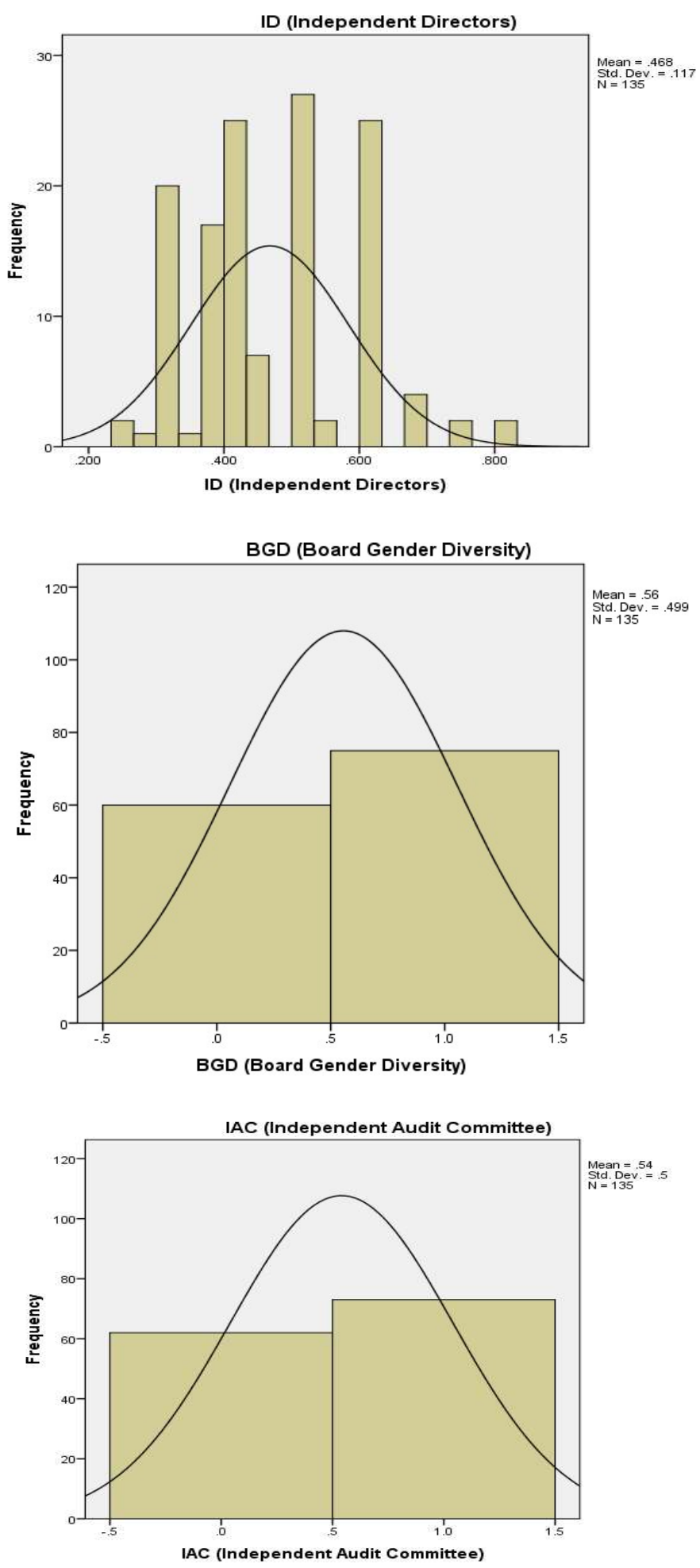

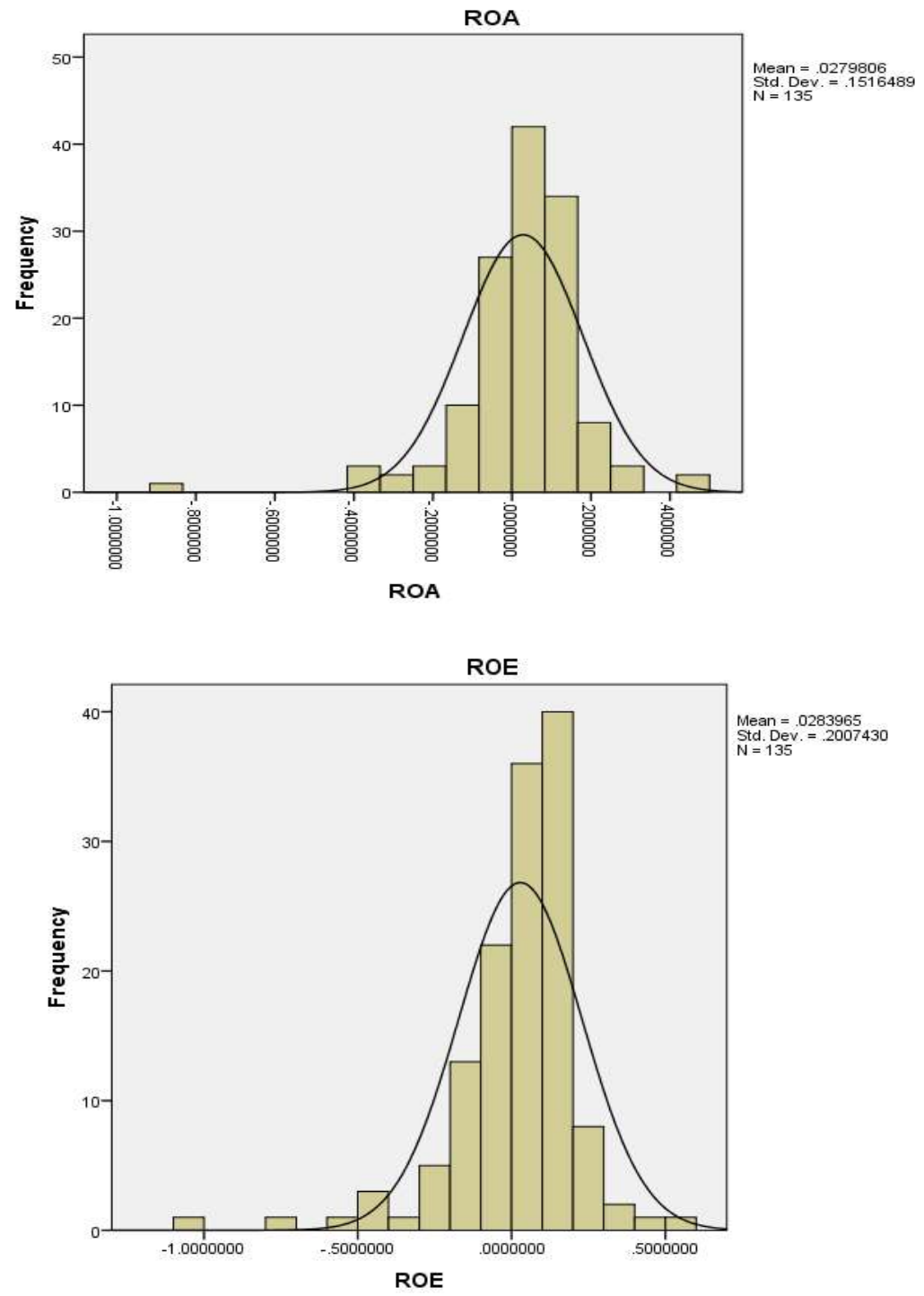

Figure 1. Distribution Curves for Variables

\section{Pearson Correlation Analysis}

This study adopted the Pearson $r$ correlation test to investigate the relationship between variables. This analysis measures the strength of the relationship and significant bivariate relationship among the variables. Thus, it will provide an indication of the significance and the direction of the relationship as well as to check potential multicollinearity problem.

The Pearson correlation analysis of the independent variables i.e. the three corporate governance attributes is presented in Table 3. The Pearson correlation analysis of the dependent variables (financial performance measures) is shown in Table 4. Finally, Table 5 provides the Pearson correlation analysis of the independent variables (corporate governance attributes) and the dependent variables (financial performance measures).

Table 3. Pearson Correlations Independent Variables

\begin{tabular}{|l|c|c|c|c|}
\hline & & ID & BGD & IAC \\
\hline \multirow{4}{*}{ ID } & Pearson Correlation & 1 & -.061 & $.326^{*}$ \\
\cline { 2 - 5 } & Sig. (2-tailed) & & .485 & .000 \\
\cline { 2 - 5 } & N & 135 & 135 & 135 \\
\hline \multirow{4}{*}{ IAD } & Pearson Correlation & -.061 & 1 & .106 \\
\cline { 2 - 5 } & Sig. (2-tailed) & .485 & 135 & 135 \\
\cline { 2 - 5 } & $\mathrm{N}$ & 135 & -.106 & 1 \\
\cline { 2 - 5 } & Pearson Correlation & $.326^{*}$ & .220 & 135 \\
\cline { 2 - 5 } & Sig. (2-tailed) & .000 & 135 & 135 \\
\cline { 2 - 5 } & $\mathrm{N}$ & 135 & 135 & 135 \\
\hline
\end{tabular}

Notes: Correlation is significant at the 0.01 level (2-tailed).

Source: by authors through secondary data analysis. 
Table 3 shows the results of the correlation analysis of the three variables used for corporate governance attributes. According to the correlation analysis, with the exception of independent directors and independent audit committee, none of the other variables used were significantly correlated. There is a significant and positive relationship between independent directors and an independent audit committee at $\mathrm{p}<0.01$ (correlation coefficient $=0.326$ ).

Table 4. Pearson Correlations Dependent Variables

\begin{tabular}{|c|c|c|c|}
\hline \multirow{3}{*}{ ROA } & & ROA & ROE \\
\cline { 2 - 4 } & Pearson Correlation & 1 & $.972^{*}$ \\
\cline { 2 - 4 } & Sig. (2-tailed) & 135 & .000 \\
\hline \multirow{3}{*}{ ROE } & N & $.972^{*}$ & 135 \\
\cline { 2 - 4 } & Pearson Correlation & .000 & 1 \\
\cline { 2 - 4 } & Sig. (2-tailed) & 135 & 135 \\
\hline
\end{tabular}

Notes: Correlation is significant at the 0.01 level (2-tailed).

Source: by authors through secondary data analysis.

The results of the correlation analysis of the two variables used for financial performance is provided in Table 4. There is a highly significant and positive relationship between return on asset and return on equity at $\mathrm{p}<$ 0.01 (correlation coefficient $=0.972$ ).

Table 5. Pearson Correlations Average for all Variables

\begin{tabular}{|c|c|c|c|c|c|c|}
\hline & & ID & BGD & IAC & ROA & ROE \\
\hline \multirow{3}{*}{ ID } & Pearson Correlation & 1 & -.061 & $.326 * *$ & -.148 & -.138 \\
\hline & Sig. (2-tailed) & & .485 & .000 & .087 & .111 \\
\hline & $\mathrm{N}$ & 135 & 135 & 135 & 135 & 135 \\
\hline \multirow{3}{*}{ BGD } & Pearson Correlation & -.061 & 1 & -.106 & $.193^{*}$ & .162 \\
\hline & $\begin{array}{l}\text { Sig. (2-tailed) } \\
\end{array}$ & .485 & & .220 & .025 & .061 \\
\hline & $\mathrm{N}$ & 135 & 135 & 135 & 135 & 135 \\
\hline \multirow{3}{*}{ IAC } & Pearson Correlation & $.326^{* *}$ & -.106 & 1 & -.137 & -.110 \\
\hline & Sig. (2-tailed) & .000 & .220 & & .114 & .205 \\
\hline & $\mathrm{N}$ & 135 & 135 & 135 & 135 & 135 \\
\hline \multirow{3}{*}{ ROA } & Pearson Correlation & $\begin{array}{l}-.148 \\
\end{array}$ & $.193^{*}$ & -.137 & 1 & $.972^{* *}$ \\
\hline & Sig. (2-tailed) & .087 & .025 & .114 & & .000 \\
\hline & $\mathrm{N}$ & 135 & 135 & 135 & 135 & 135 \\
\hline \multirow{3}{*}{ ROE } & Pearson Correlation & -.138 & .162 & -.110 & $.972^{* *}$ & 1 \\
\hline & Sig. (2-tailed) & .111 & .061 & .205 & .000 & \\
\hline & $\mathrm{N}$ & 135 & 135 & 135 & 135 & 135 \\
\hline
\end{tabular}

Notes: Correlation is significant at the 0.05 level (2-tailed).

Source: by authors through secondary data analysis.

According to the results of the correlation analysis in Table 5, with the exception of board gender diversity and ROA, none of the other variables used were significantly correlated.

The results indicate that independent directors is inversely correlated with financial performance as indicated by its statistically insignificant correlation coefficients with ROA and ROE ( $>>0.05)$ and correlation (ROA: $r$ $=-0.148$; ROE: $\mathrm{r}=-0.138$ ).

In terms of board gender diversity, results in Table 5 suggest that the presence of women directors on the board is positively and significantly correlated with ROA at $\mathrm{p}<0.05$ (Pearson's correlation coefficient $=$ 0.193). However, there was a positive but insignificant relationship between such corporate governance characteristic with ROE ( $p>0.05)$ and correlation (ROE: $r=0.162)$.

According to Table 5, it is found that the independent audit committee is insignificantly correlated to financial performance irrespective employed to represent financial performance (ROA and ROE). This is based on evidence of its $p$-value which are $>0.05$ and correlation (ROA: $r=-0.137$ and ROE: $r=-0.110$ ).

Guildford's (1973) Rule of Thumb is used to analyze the above results to interpret the strength of the correlation between variables. According to this rule, a correlation coefficient of below 0.20 shows a 'negligible' relationship; 0.20 to .040 means a 'low' relationship; 0.41 to 0.70 indicates a 'moderate' relationship; 0.70 to 0.90 shows a 'high' relationship; and a coefficient of more than 0.90 suggests a 'very high' relationship (Guildford, 1973). The correlation matrix in Table 5 shows that there is no multicollinearity because there are no variables correlate above 0.7 ; hence all variables are being considered for regression analysis. Following are some figures showing the pattern of relationship between independent and dependent variables through $3 \mathrm{D}$ scatterplot. 

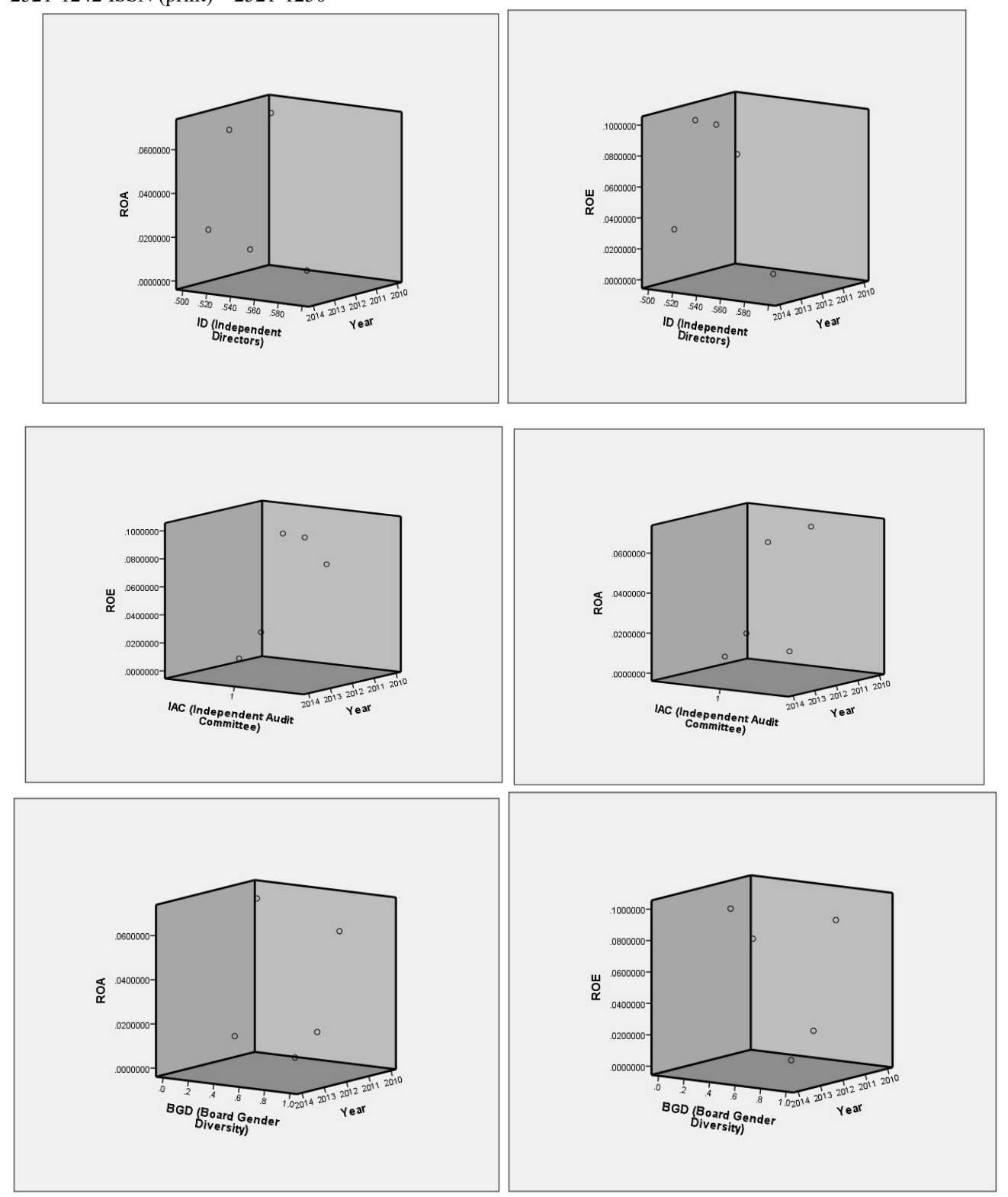

Figure 2. 3D Scatterplot for the Independent and Dependent Variables

\section{Correlogram}

Correlogram is a graph of the correlation matrix. It is used to highlight the most correlated variables in a data table. In the following figure 3, correlation coefficients are colored according to the value.

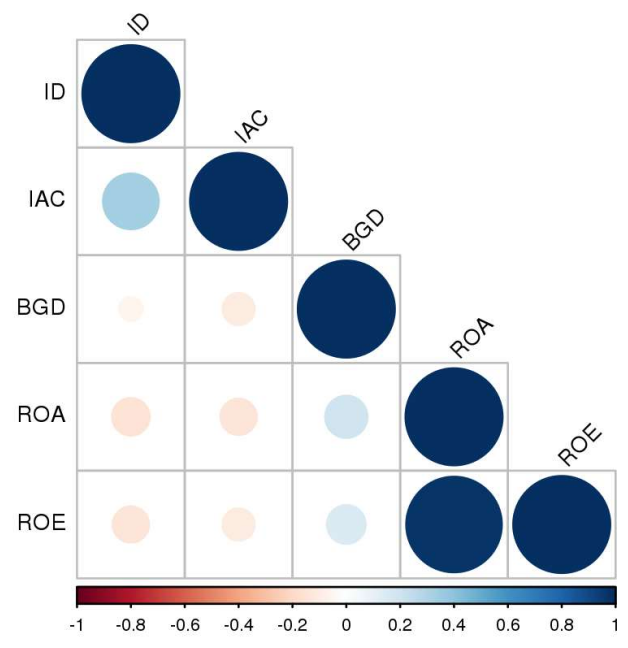

Figure 3. Correlogram of the Variables 


\section{Regression Analysis}

This study consists of two models. In the first model, ROA is the dependent variable and ROE is the dependent variable in the second model. Taking both variables as the following results have been obtained

Table 6 demonstrates the five years summary of regression analysis from 2010 to 2014 .

\begin{tabular}{|l|c|c|c|c|c|}
\hline Model & $\mathrm{R}$ & $\mathrm{R}$ Square & Adjusted R Square & $\begin{array}{c}\text { Std. Error of } \\
\text { the Estimate }\end{array}$ & Durbin-Watson \\
\hline 1 & 0.249 & 0.062 & 0.040 & 0.1485518106 & 2.045 \\
\hline 2 & 0.213 & 0.046 & 0.024 & 0.1983513475 & 2.102 \\
\hline
\end{tabular}

Source: by authors through secondary data analysis.

Independent Variable: ID (Independent Directors), BGD (Board Gender Diversity) and IAC (Independent Audit Committee).

Dependent Variable: ROA (Return on Asset) (Model 1)

Dependent Variable: ROE (Return on Equity) (Model 2)

Tabachnick and Fidell (2007) suggested that for a small sample, the reporting of adjusted R square value is considered to be more appropriate. This is because the adjusted $\mathrm{R}$ square statistic corrected the "optimistic value" that occur in a small sample to provide a better estimation of the exact population value. Considering the small sample of the study, the value of Adjusted R Square shall be considered as reporting value.

Based on Table 6, for model 1, the Adjusted R Square is 0.062 that indicates, $6.2 \%$ of the alteration in ROA could be explained by the alteration in ID, BGD, and IAC as independent variables. Whereas, for model 2, the Adjusted R Square of 0.046 indicates, that $4.6 \%$ of the alteration in ROE could be explained by the alteration in all independent variables.

Table 7. ANOVA

\begin{tabular}{|c|c|c|c|c|c|c|}
\hline Model & & Sum of Squares & df & Mean Square & $F$ & Sig. \\
\hline \multirow{3}{*}{1} & Regression & 0.191 & 3 & 0.064 & 2.882 & 0.038 \\
\hline & Residual & 2.891 & 131 & 0.022 & & \\
\hline & Total & 3.082 & 134 & & & \\
\hline \multirow{3}{*}{2} & Regression & 0.246 & 3 & 0.082 & 2.084 & 0.105 \\
\hline & Residual & 5.154 & 131 & 0.039 & & \\
\hline & Total & 5.400 & 134 & & & \\
\hline $\begin{array}{l}\text { Indepen } \\
\text { Depend } \\
\text { Depend }\end{array}$ & $\begin{array}{l}\text { dent Variable } \\
\text { nt Variable: } \\
\text { nt Variable: }\end{array}$ & $\begin{array}{l}\text { ndent Directors), } \\
n \text { on Asset) (Mod } \\
n \text { on Equity) (Mo }\end{array}$ & & & & \\
\hline
\end{tabular}

Source: by authors through secondary data analysis.

Table 7 tests the null hypothesis that multiple $\mathrm{R}$ in the population equals 0 . With $\mathrm{Sig}=0.0038$; means that $\mathrm{p}<0.0005$, indicated that model 1 did not reach statistical significance. Model 2 is also not statistically significant as $\mathrm{Sig}=0.105$. This specifies that all the variables of corporate governance attribute including ID, BGD and IAC do not predict financial performance measured using ROA and ROE from the year 2010 to 2014 averagely.

Following are some graphs showing the regression plots of the study.

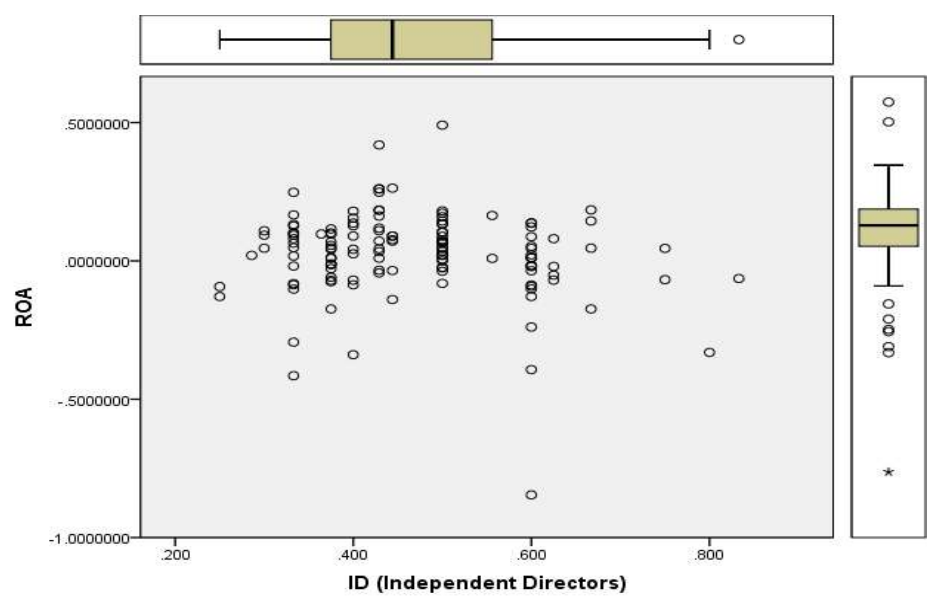



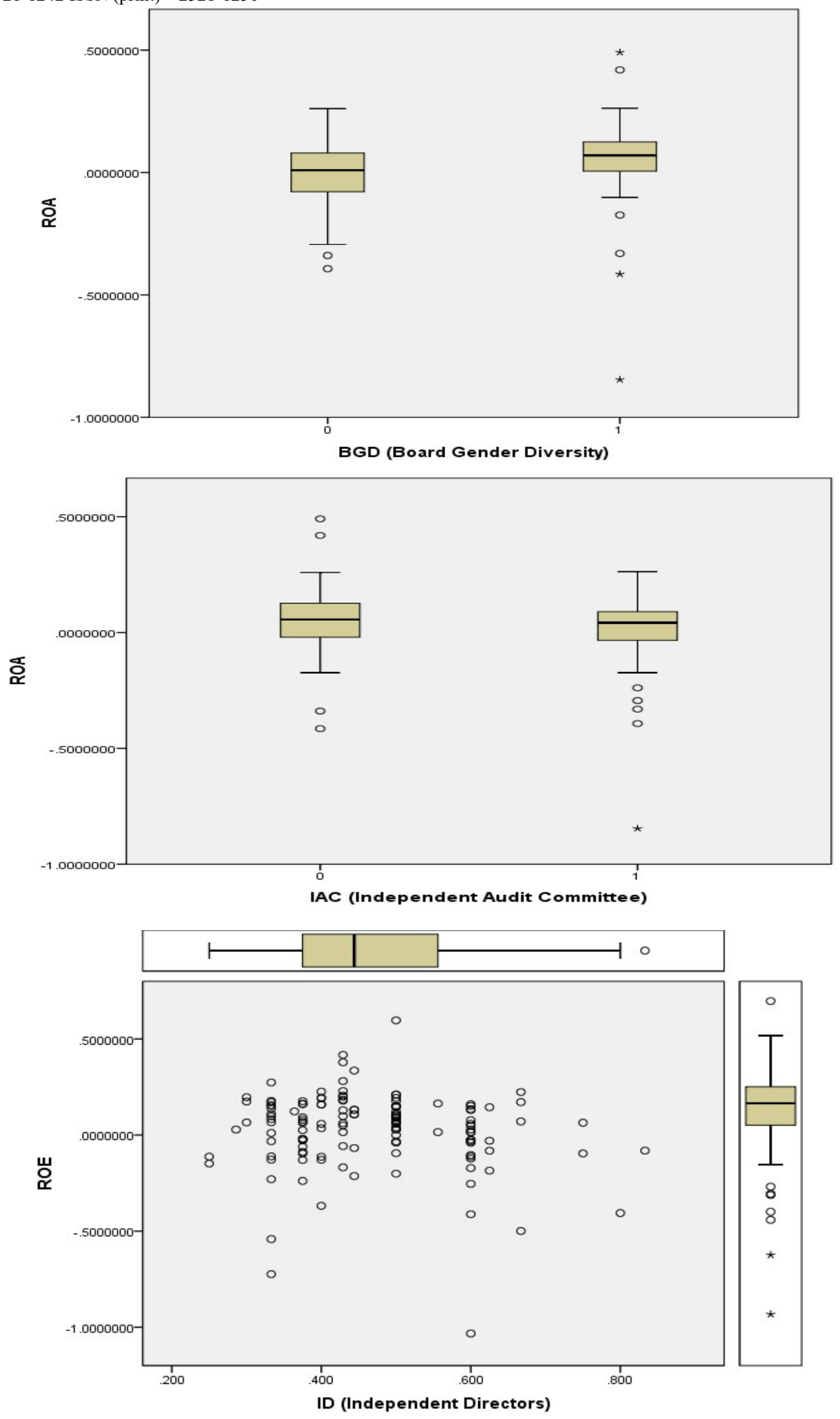

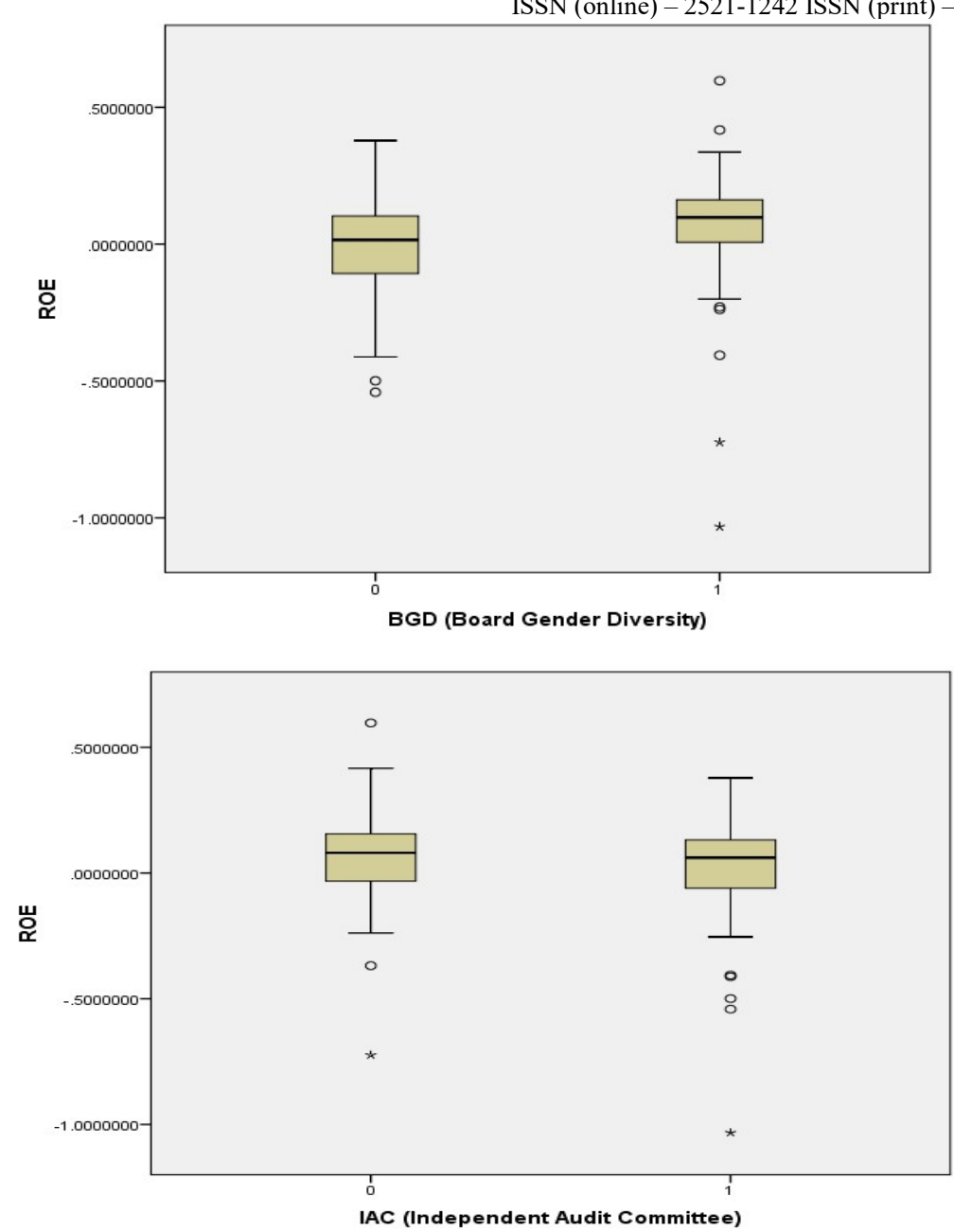

Figure 4. The summary of the regression results

Figure 4 shows the summary of the regression results for the two models

ROA (Average 2010 - 2014) $=0.78-0.143 \mathrm{ID}+0.054 \mathrm{BGD}-0.025 \mathrm{IAC}$

ROE (Average 2010 - 2014) $=0.096-0.189 \mathrm{ID}+0.060 \mathrm{BGD}-0.023 \mathrm{IAC}$

The findings from multiple regressions clearly indicate mixed results between the corporate governance variables and the financial performance variables measured using ROA and ROE respectively. Based on the multiple regression results, negative and insignificant associations between independent directors and ROA as well as ROE are suggesting that board independence is not connected with performance as indicated by its statistically insignificant coefficients with ROA and ROE. (ROA: $\beta=-0.110, p=0.220$; ROE: $\beta=-0.110, p$ $=0.226$ ). This means that having the presence of independent directors on the board does not influence the different measures of financial performance of ROA and ROE. The first hypothesis (H1) of the study was that the presence of independent directors on the board has a positive relationship with financial performance. The results of the regression analysis reject the hypothesis $(\mathrm{H} 1)$.

Contrary with the findings of Kamardin \& Haron (2011), Saat et al (2011), Khan and Awan (2012) as well as Ma and Tian (2009) which shows that independent directors are significantly related to the performance of a company, the results of the regression analysis reject the hypothesis (H1). However, such results are supported with the study conducted by Annuar \& Shamser (1994) which provided that there was no significant effect of board composition on the wealth of the companies. Other studies supporting the result of the regression analysis are Ponnu (2010), Paul et al. (2011) as well as Sakawa, Watanabel, and Ben-Zion (2009).

Hence, it can be seen that for the technology industry, independent directors have an insignificant and negative effect on the company's financial performance. This may be due to the specific characteristics of the industry where non-independent directors with actual links to the company may be able to contribute better to the company as they would have more hands-on knowledge on the industry. It was discussed by Al-Matari et al. (2012) that such insignificance might be partly due to the limited oversights provided by non-executive directors. 
Financial Markets, Institutions and Risks, Volume 3, Issue 1, 2019

ISSN (online) - 2521-1242 ISSN (print) - 2521-1250

For board gender diversity, the multiple regressions results suggest such corporate governance characteristic is positively and significantly correlated with financial performance using ROA as a financial measurement. This is indicated by its statistically significant regression coefficients with ROA where $p<0.05$. (ROA: $\beta=$ $0.178, \mathrm{p}=0.039$ ). This means that the null hypothesis is rejected and $\mathrm{H} 2$ is supported. Conversely, for the association between board gender diversity and financial performance measured using ROE, it is found that board gender diversity does not have a positive and significant relationship as indicated by its regression coefficients with ROE. (ROE: $\beta=0.149, \mathrm{p}=0.085$ ).

It can be seen that this study on the relationship between board gender diversity and firm performance has produced mixed results. The positive and significant relationship between board gender diversity and ROA is supported by many studies including Campbell \& Vera (2009) and Carter et al. (2003). However, the negative and comparatively insignificant relationship between board gender diversity and ROE are in support of the investigations conducted by Bøhren \& Strøm (2007), Haslam et al. (2010), Shukeri et al. (2012) and Marimuthu \& Kolandaisamy (2009). This inconclusive result may be due to whether the women directors are appointed as board members as mere tokens. Tokenism assumes that a token, i.e. a minority individual, has symbolic value, but does not necessarily impact group decision-making processes in a substantial way (Kanter, 1977).

The findings found that an independent audit committee has an inversely significant association with financial performance irrespective of measure employed to describe firm financial performance (ROA or ROE). The result is statistically represented by (ROA: $\beta=-0.082, p<0.01$; ROE: $\beta=-0.058, p<0.01$ ). The findings discovered an insignificant association between the independent audit committee and financial performance. Therefore, the hypothesis (H3) that the positive association between the independent audit committee and financial performance for Malaysian technology companies during the 2010 to 2014 period is rejected. The results propose that the independent audit committee depends on the independence of the board itself.

The regression result is consistent with the study by Kajola (2008) where it was found that having a majority of independent non-executive directors in the audit committee does not have a significant influence on firm performance. Other studies in support of the result included the study Ghabayen (2012) on the listed companies in the Saudi market and Klein (1998) on S\&P 500 companies. The result, however, in contrast with the findings by Chan and Li (2008), Hamdan, Sarea and Reyad (2013) and Tornyeva and Wereko (2012) where there was a significantly positive relationship between the independent audit committee and financial performance.

\section{Summary of Findings}

While the objective of this study is to find the relationship between corporate governance attributes and financial performance of Malaysian technology companies, the result and evidence suggest that there is insufficient proof to ascertain that companies with good corporate governance practice accomplish better than companies which do not carry out such practice. In terms of the significance of the relationship, findings using correlation analysis show that the presence of more independent directors and have an independent audit committee has a negative and insignificant relationship with ROA and ROE. Whilst, the remaining independent variables i.e. board gender diversity showed a positive and significant relationship with the financial performance of the companies.

\section{Conclusion}

As a final sentiment, it is anticipated for the study to act as an avenue to contribute positively towards encouraging a good governance practice among corporations particularly the Malaysian technology companies. It is indeed crucial for companies to ensure that the adoption of good governance practice is not solely based on the requirement by the regulatory body, but more towards gaining confidence from investors to increase the firm's value. In conclusion, this study shows that the presence of more independent directors has a negative relationship with ROA and ROE for the technology companies in Malaysia. The same goes for an independent audit committee. Whilst, there was a positive relationship between board gender diversity with ROA and ROE.

\section{References}

1. Abid. G and Ahmed, A. (2014). Failing in Corporate Governance and Warning Signs of a Corporate Collapse. Pakistan Journal of Commerce and Social Sciences, 8 (3), 846-866.

2. Abdullah, S.N., K.N.I. Ku Ismail and L. Nachum (2013). Does having women on boards create value? 
The impact of societal perceptions and corporate governance in emerging markets. Working paper.

3. Abdullah, S. N. (2004). Board composition, CEO duality, and performance among Malaysian listed companies. Corporate Governance: The International Journal of Business in Society, 4(4), 47 - 61.

4. Adams, R. and Ferreira, D. (2009). Women in the boardroom and their impact on governance and performance. Journal of Financial Economics, 94, 291-309.

5. Ahmed Haji, A. (2014). The relationship between corporate governance attributes and firm performance before and after the revised code. International Journal of Commerce and Management, 24(2), $134-151$

6. Annuar, M.N. and Shamsher, M. (1994). The Wealth Effect of Appointments and Resignations of Board of Directors. The Malaysian Management Review. 29(2), 44-52.

7. Boone, A. L., Field, L. C., Karpoff, J. M. and Raheja, C. G. (2007). The determinants of corporate board size and composition: An empirical analysis. Journal of Financial Economics, 65-101.

8. Booth, J. R., and Deli, D. N. (1996). Factors affecting the number of outside directorships held by CEOs. Journal of Financial Economics, (1), 81-104.

9. Cadbury, A (1992). Report of the Committee on the Financial Aspects of Corporate Governance: The Code of Best Practice. Gee Professional Publishing. London, December.

10. Christopher M Bishop. Pattern recognition and machine learning. springer, 2006

11. Campbell, K. and Minguez-Vera, A. (2008). Gender Diversity in the Boardroom and Firm Financial Performance. Journal of Business Ethics, 83, 435-451.

12. Cooper, D.R. \& Schindler, P.S. (2003). Business Research Methods. (8th ed.). Boston: McGraw-Hill Irwin.

13. Dezsö, C. L. and Ross, D. G. (2012). Does female representation in top management improve firm performance? A panel data investigation. Strategic Management Journal, 1072-1089.

14. Fama F. M. and Jensen, M. C. (1983). Separation of Ownership and Control. Journal of Law and Economics, Vol. XXVI.

15. Ghazali Z. and Abdul Manab, N. (2014). Code of Corporate Governance as a Catalyst to Companies' Performances: A Review of Malaysian Experience. World Review of Business Research, 4(2), 49 - 60.

16. Gompers, P. A., Joy L. I. and Metrick, A. (2003). Corporate Governance and Equity Prices. Quarterly Journal of Economics, 118, 1.

17. Haniffa, R., \& Hudaib, M. (2006). Corporate Governance Structure and Performance of Malaysian Listed Companies. Journal of Business Finance and Accounting, 33(7-8), 1034-1062.

18. Hashim, H. A., and Devi. S. (2008). Board characteristics, ownership structure, and earnings quality: Malaysian evidence, in Mathew Tsamenyi, Shahzad Uddin (ed.) Corporate Governance in Less Developed and Emerging Economies (Research in Accounting in Emerging Economies, 8. Emerald Group Publishing Limited, 97 - 123.

19. Haslam, S. A., Ryan, M. K., Kulich, C., Trojanowski, G. and Atkins, C. (2010) Investing with Prejudice: The Relationship Between Women's Presence on Company Boards and Objective and Subjective Measures of Company Performance. British Journal of Management, Vol. 21, 484-497.

20. High-Level Finance Committee on Corporate Governance of Malaysia. (1999). Report on Corporate Governance in February 1999.

21. Ho, S. M. S., \& Wong, K. R. (2001). A study of the relationship between corporate governance structures and the extent of voluntary disclosure. Journal of International Accounting, Auditing, and Taxation, 10(2), 139-156.

22. Hussin, N. and Othman, R. (2012). Code of Corporate Governance and Firm Performance. British Journal of Economics, Finance and Management Sciences, 6 (2).

23. Johari, N., Mohd Saleh, N., Jaffar, R. and Hassan, M.S. (2008). The influence of board independence, competency, and ownership on discretionary accruals in Malaysia. International Journal of Economics and Management, 2(2):281-306. 
Financial Markets, Institutions and Risks, Volume 3, Issue 1, 2019

ISSN (online) - 2521-1242 ISSN (print) - 2521-1250

24. Kamardin, H. and Haron, H. (2011). Internal corporate governance and board performance in monitoring roles: Evidence from Malaysia. Journal of Financial Reporting and Accounting, 9 (2), 119 - 140.

25. Khas, M. N. (2002). Corporate governance in Malaysia: issues \& challenges, Colloquium for UiTMMICG Corporate Governance Research Centre, UiTM, Shah Alam.

26. Klapper, L. F. and Inessa L. (2004). Corporate Governance, Investor Protection, and Performance in Emerging Markets. Journal of Corporate Finance, 10, 703-728.

27. Lückerath-Rovers, M. (2013). Women on boards and firm performance. Journal of Management \& Governance, Volume 17(2), 491-509.

28. Mak, Y.T., and Y. Kusnadi (2005). Size really matters further evidence on the negative relationship between board size and firm value. Pacific-Basin Finance Journal, 13, 301-318.

29. Marimuthu, M. and Kolandaisamy, I. (2009). Ethnic and Gender Diversity in Boards of Directors and Their Relevance to Financial Performance of Malaysian Companies. Journal of Sustainable Development, 2, 3.

30. MCCG. (2012). Malaysian Code of Corporate Governance. Malaysian Law Journal Sdn Bhd, Malaysia.

31. Mohd Ghazali, N. A. (2010). Ownership structure, corporate governance and corporate performance in Malaysia. International Journal of Commerce and Management, Vol. 20, Issue 2, 109 - 119.

32. Mokhtar, S.M., Sori, Z.M., Hamid, M.A., Abidin, Z.Z., Nasir, A.M., Yaacob, A.S., Mustafa, H., Daud, Z.M., \& Muhamad, S. (2009). Corporate governance practices and firms performance: the Malaysian case. Journal of Money, Investment and Banking, 1 1,45-59.

33. Noordin, H. (1999). Strengthening the Audit Mechanism, Akauntan Nasional, April, 24.

34. OECD Principles of Corporate Governance (2004). http://www.oecd.org/daf/ca/ corporatego vernanceprinciples/31557724.pdf. Accessed 26 April 2015.

35. Ponnu, C. H. and Karthigeyan R.M. (2010). Board independence and corporate performance: Evidence from Malaysia. African Journal of Business Management, 4(6), 858-868.

36. Saat, N. A., Karbhari, Y., Heravi, S., \& Nassir, A. M. (2011). Effective Oversight Roles of Board of Directors - The Case of Listed Firms on Bursa Malaysia. World Review of Business Research, 1 (1), 231-245.

37. Shukeri, S. N., Ong, W. S. and Shaari, M.S. (2012). Does the board directors' characteristics affect firm performance? Evidence from Malaysian public listed companies. International Business Research, Vol. 5, No. 9, 120-129.

38. Solomon. J. (2010). Corporate Governance \& Accountability. Chichester: John Wiley \& Sons.

39. Sulaiman, A. and Joriah M. (2012). Introduction to corporate governance from an Islamic perspective. Humanomics, 28(3), $220-231$.

40. Tham, J. and Romuald, D. F. (2012). The Impact of Corporate Governance Mechanism and Corporate performance: A study of Listed Companies in Malaysia. Journal for the Advancement of Science \& Arts, Vol. 3,1 .

41. World Bank (1998). East Asia: The Road to Recovery. Oxford, UK: Oxford University Press.

42. Yasser, Q. R. (2012). Effects of Female Directors on Firms Performance in Pakistan. Modern Economy, 3(7), 817-825.

43. Zainal Abidin, N A. \& Ahmad, H. (2007). Corporate governance in Malaysia: The effect of corporation reforms and state business relation in Malaysia. Asian Academy of Management Journal, 12 (1), $23-34$.

44. Imam, T, Ahmed, A and Tickle, K 2012, 'Relating firm performance to corporate governance characteristics: a research perspective on the publicly listed information technology companies in Australia', Corporate Ownership and Control, 9(2), 106-122.

45. Haron, Razali and Ibrahim, Khairunisah and Muhamad, Nordin (2008) Board of directors, strategic control and corporate financial performance of Malaysian listed construction and technology companies: an empirical analysis. The ICFAI University Journal of Corporate Governance, VII (4), 18-33. ISSN 0972-6853. 